\title{
Scorpaena scrofa: A Promising Aquaculture Candidate for Sicilian Aquaculture
}

\section{Monique Mancuso*}

Institute for Coastal Marine Environment (IAMC), National Research Council (CNR), Section of Messina, Spianata S. Raineri 86, 98122 Messina, Italy

\begin{abstract}
Scorpaena scrofa is a much appreciated species in the Mediterranean and Sicilian markets. The high quality of its meats, the excellent palatability and the high market value make this species a good candidate for the assessment on the new species farmed in aquaculture. In particular in Sicily was reported for the first time the natural spawning of S. scrofa kept in captivity at the experimental plant of Messina (IAMC-CNR). In my opinion, further experiments must be carried out, focused on: finding a suitable starting live food for red scorpion fish larvae, a suitable tanks environment to obtain a useful production of this important species.
\end{abstract}

Keywords: Scorpaena scrofa; Aquaculture; Innovative species

\section{Introduction}

The red scorpionfish, Scorpaena scrofa, is the most appreciated species among the scorpionfish in the Mediterranean and Sicilian markets and has a good potential of becoming a future candidate for marine aquaculture due to the high quality of its meat, the excellent palatability and the high market value. The species reach the sexual maturity respectively at 3 years for the females and 4 years for males [1]. The spawning period occurs from May to August and is characterized by multiple spawning events, the fertilization is external and the eggs are embedded in a gelatinous matrix [2]. In 2014 Maricchiolo et al. [3], thanks to the Research project PON02_ 3362185 "Innovaqua", reported the first case of spontaneous spawning of $S$. scrofa in captivity at the experimental plant of Messina (IAMC-CNR) obtained for a period comprised from 29 June to 18 July 2013 with 14 spawning events. Unfortunately, the lack of previous information on the mouth size and the impossibility of having living prey of suitable dimension did not allow us to continue beyond the sixth life day.
The management of red scorpionfish broodstock, is to be considered as a starting point to obtain spontaneous spawning in captivity and for future propagation technologies.

In my opinion, further experiments must be carried out, focused on: finding a suitable starting live food for red scorpion fish larvae, a suitable tanks environment to obtain a useful production of this important species.

\section{References}

1. Bradai MN, Bouain A (1991) Reproduction de Scorpaena porcus et de Scorpena scrofa (L.,1758) (Pisces, corpaenidae) du Golfe de Gabes. Oebalia XVII, 167-180.

2. Jakov DULČIĆ, Jurica JUG-DUJAKOVIĆ, Vlasta BARTULOVIĆ, Branko GLAMUZINA, Edhem HASKOVIĆ et al. (2007) Embryonic and larval development of large scaled scorpionfish scorpaena scrofa (scorpaenidae). Cybium 31: 465-470

3. Maricchiolo G, Casella G, Mancuso M, Genovese L (2014) The first episode of spontaneous spawning in captive red scorpionfish, scorpaena scrofa (linnaeus 1758). Aquaculture Research 1-4.
*Corresponding author: Monique Mancuso, Institute for Coastal Marine Environment (IAMC)-National Research Council (CNR)-Section of Messina, Spianata S. Raineri 86, 98122 Messina, Italy, E-mail: monique.mancuso@iamc.cnr.it

Received July 06, 2015; Accepted July 08, 2015; Published August 06, 2015

Citation: Mancuso M (2015) Scorpaena scrofa: A Promising Aquaculture Candidate for Sicilian Aquaculture. J Aquac Res Development 6: 375. doi:10.4172/21559546.1000375

Copyright: (c) 2015 Mancuso M. This is an open-access article distributed under the terms of the Creative Commons Attribution License, which permits unrestricted use, distribution, and reproduction in any medium, provided the original author and source are credited. 